DOI 10.32370/2018_09_4

\title{
Children's Literature Tracks in Disney Films and Azerbaijani Children's Auditorium
}

\author{
Abdullayeva Turana Madar \\ Baku Engineering University
}

\begin{abstract}
As we know, Walt Disney, a filmmaking organization in the 20th century, has produced films that have been loved not only in his homeland, but also far from his homeland. Among these films, films produced for children have attracted more attention, and the young American children's literature, has begun to bring its effect to a small audience. The close relationship between Disney films and children literature has had an indispensable impact on the development of American children's literature. The animated films that they watched make children the desire to read literature. The parents, who have come to appreciate all of this, have drawn them to education. Walt Disney films are among the famous animated films not only in America, but also in many countries all over the world.
\end{abstract}

Keywords: cartoon, Disney film, animation, innovator

Walt Disney was born on 5 December 1901 in Chicago in a very poor family who came originally from Irish, English and German. He has been working as a cartoon artist in Kansas City since 1919. Later, he joined the Disney advertising campaign and started working with Ub Iwerks. Together they made Disney's famous heroes, drawing cartoons and creating a film called "The Laugh of Laughter." In this form, the first commercials started functioning. After that, Walt Disney created his own "Laugh O Gram", a very small personality. Like Walt Disney, almost no one has been rich in fantasy. The talented artist worked as an ambulance driver during the First World War. He died of lung cancer in 1966 [2].

In 1921, after World War I, Walt Disney returned to Kansas and started a business relationship with the animator Ub Iwerks. Walt Disney has created great talent "Red Hat", "Cat in Boots" and others. The two-part animated film "Alisa in the Land of Wonders" created an animated film. In addition, a new film, "Osvald - Happy Rabbit" was released by the company during this period. The new personality, Mickey Mouse, appeared in Disney's film which is called "Wrecked Aircraft. The new personality's name was given by Walt's wife, Lillian. Mickey Mouse was awarded the Disney "Oscar" award in 1932 for the creation of her personality. In 1939, Leon Schlesinger noted about Mickey Mouse at "Look"- "Today's animation is a great fun for young and old people, but first of all, it's fun for kids. That's why we always have to make the products fit into children's thinking" [6]. At the beginning of the 
1930s, Disney's painting techniques developed, and it had a strong impact on the psychology of the Americans. Especially children's characters created on animals became more and more objects of interest.

Ub Iwerks has had an invaluable role in the emergence of the original Disney heroes. Starting in the 1930s, Walt Disney has already had a strong status in the animation field. The company was very sensitive to this work because it takes its products for children [4]. As you can see, many of these characters were created on the basis of heroes of folk tales. The company understood very well that these tales were favorite of all children, and the animation of these subjects would lead to more children watching. Disney's film cartoon was "Snow White and the Seven Dwarfs" which film based on the German fairy tale by the Brothers Grimm, it is the first full-length animated feature film and the earliest Disney animated feature film. Disney films have appealed not only to American children's literature, but also to many oral and written children's literature in the world. Therefore Disney children's films were quite diverse.

In 1933, Disney producued the first colorful cartoon in the world. This animated film, "Three Little Pigs", was based on the motifs of English tales and Disney was awarded Oscar for the second time.

The 40's of the 20th century, it is a sensitive period in world literature like world history. Changes in society have affected one form of literature and culture. Among the middleclass Americans, the Great Depression, which started before the Second World War, continued during the war. At this period, parents' fears and feelings of insecurity have not been neglected by the children's upbringing and relationships with the community. Literary critics have tried to be careful when describing this period. For example, C. Anderson Aldrich and Mary Aldrich argued that children forced to adhere to the strict regimes of management-oriented childrearing were likely to grow into adults who were unspontaneous, efficient, and cold: "Anyone who has watched a mechanical robot perform his incredible acts of skill, has probably been conscious not only of wonder but also of a certain obscure impression of fear. The spectacle of someone acting correctly without feeling anything is so inhuman that it is vaguely unpleasant" [1].

In 1941, film-maker was paying close attention to the new this Dumbo. This film was a start to finding of children's literature among children's films. Particularly, the film focuses on issues such as the upbringing of children, the elimination of contemporary concerns about 
the proper upbringing of children, the regulation of social and cultural relations. The film "Dumbo" can be understood as part of children's literature. Here are some basic reasons to think so. First, it appears that from the day Disney was created, films are seen as potential competitors in the middle class and demonstrate selective literature on children's education and upbringing. Secondly, Hollywood has long worked for children in the context of the combination of films. When Disney started producing long-term cartoons in the late 1930s, these films included not only smaller essays like Collodi, but also from children's literature covering the classic works of the eighteenth and nineteenth centuries, from Perult and Grimm [8].

In fact, Disney films (and books, dresses and toys) were a school to create a message expressing parents' democratic desires for success in capitalist society in a centuries-old history. At the end of the 19th century, since the opening of the modern film industry, there was a sense of fear about the impact of the film on the child's developing mind, so censorship and argumentation on films appeared [3]. Therefore, state control over the newly created film industry was strong, the content of movies with melodrama, crime, and open romance scenes that had been found to be inappropriate for adults, was allegedly caused by "early premature growth" of children., these types of films could have a negative impact on their psychological status and upbringing, taking into account all of this, the company has professionally chosen the themes and heroes of the films it creates.

Overall, Disney films which were produced from the 1930's till today, have once again proved its relevance to children's literature. "Snow White", 1937, "Pinocchio", 1940, "Dumbo" 1941, "Bambi", 1942, "Song of the South", 1946, "Wind in the Willows", 1949, "Cinderella", 1950, "Alisa in Wonderland", 1951, "Peter Pen", 1953 and "Sleeping Beauty", 1959, “The Jungle Book”, 1967, “The Wild Country”,1970, “The Million Dollar Duck”, 1971, "Robin Hood" 1973, “The Many Adventures of Winnie the Pooh", 1977, "The Little Mermaid”, 1989,“All Dogs Go To Heaven”, 1989, “Lion King”, 1994 and so on are among the films that are in the hearts of children. These animated films, based on the integration of classic folk tales and works, were not only distracted by the children, but also their adults.

Walt Disney has not been left out of politics among the views expressed in his films. With a number of films, he delivers some skillful political views [9]. As an example, let's look at the film "Jungle book". "The Jungle Book" is actually reflected in the colonial policy of 
Britain in India. Even though I would say that the company wanted to show Mowgli as a Briton, and the animals what helped Mowgli as Indians. At the end of film Mowgli abandoned animals and the place where he grew up, resembled British politics after colonialism.

Like many other countries in the world, in the Republic of Azerbaijan children are also fond of Walt Disney movies. The best examples of foreign literature were studied on the basis of these films by Azerbaijani children's audiences. These films play an indispensable role in the development of children as individuals in society.

Overall, today Walt Disney is the world's number one for Oscar winner. He has won 26 Oscar in total. It is once again proved that makes the Disney films and children's literature closer to each other. All of this, in turn, affects the development of American children's literature in a positive sphere in most countries of the world.

\section{References}

1. Aldrich, C. Anderson, and Mary M. Aldrich. Babies Are Human Beings: An Interpretation of Growth. New York: Macmillan, 1938

2. Barrier, Michael. The Animated Man: The Life of Walt Disney. Berkeley: $U$ of California P, 2007

3. Couvares, Francis G., ed. Movie Censorship and American Culture. Washington: Smithsonian Institution Press, 1996

4. Gould, Stephen Jay. The Panda's Thumb: More Reflections in Natural History. New York: Norton, 1980

5. Mitman, Gregg. Reel Nature: America's Romance with Wildlife on Film. Cambridge, MA: Harvard UP, 1993

6. Sampson, Henry. That's Enough, Folks: Cartoon Images in Animated Cartoons, 1900- 1960. London: Scarecrow Press, 1998

7. Sammond, Nicholas. Babes in Tomorrowland: Walt Disney and the Making of the American Child, 1930-1960. Durham: Duke UP, 2005

8. For a discussion of the place of the fairy tale in mass culture, see Zipes. For a discussion of Disney's marketing to children, see deCordova 1983 and 1994

9. https://www.indy100.com/article/10-political-messages-you-didnt-realise-werehidden-in-disney-movies--b17htesM9bb 
Translation of the Title, Abstract and References to the Author's Language

\title{
Следы детской литературы в фильмах Диснея и азербайджанская детская аудитория \\ Абдуллаева Турана Мадар \\ Бакинский инженерный университет
}

\begin{abstract}
Аннотация
Как мы знаем, Уолт Дисней, кинорежиссёрская организация в 20 веке, выпустила фильмы, которые были любимы не только на его родине, но и далеко от его родины. Среди этих фильмов фильмы, созданные для детей, привлекли больше внимания, а молодая американская детская литература начала приносить свой эффект небольшой аудитории. Тесная связь между фильмами Диснея и детской литературой оказала незаменимое влияние на развитие американской детской литературы. Анимированные фильмы, которые они смотрели, воодушевляли детей читать литературу. Родители, которые оценили всё это, привлекли их к образованию. Фильмы Уолта Диснея относятся к числу известных анимационных фильмов не только в Америке, но и во многих странах мира.
\end{abstract}

Ключевые слова: мультфильм, Дисней фильм, анимация, новатор 